\title{
Coronavirus disease 2019 and obstructive sleep apnea syndrome
}

\author{
Ahmet Cemal Pazarlı ${ }^{1}$. Timur Ekiz ${ }^{2} \cdot$ Faik $^{\text {Ilik }}{ }^{3}$ \\ Received: 3 April 2020 / Revised: 7 April 2020 / Accepted: 14 April 2020 / Published online: 28 April 2020 \\ (C) Springer Nature Switzerland AG 2020
}

\section{Dear Editor}

The publications regarding the continuing of pandemic coronavirus disease 2019 (COVID-19), caused by severe acute respiratory syndrome coronavirus 2 (SARS-CoV-2), are increasing. Increased age, hypertension, cardiovascular diseases, lung diseases, and diabetes mellitus seem to be the main risk factors for mortality in COVID-19 [1]. However, the possible association between obstructive sleep apnea syndrome (OSAS), repetitive airway collapse with apnea/hypopnea and hypoxia during sleep, and COVID-19 has not been reported yet.

Angiotensin converting enzyme 2 (ACE2) is the entry receptor of SARS-CoV-2 [2]. Of note, the increased expression of $\mathrm{ACE}$ and dysregulation of renin angiotensin system in untreated OSAS patients due to chronic intermittent hypoxia has been shown [3]. Furthermore, cardiovascular complications or comorbidities such as hypertension, heart failure, coronary artery disease, cerebrovascular diseases, diabetes mellitus, and obesity-those are also risk factors for mortality in COVID-19-are commonly seen in OSAS patients [1,4]. Fibrotic changes can also be seen after COVID-19 [5] and fibrosis was peviously shown to be a risk factor for OSAS.

To the best of our knowledge, this is one of the first reports highlighting the possible association between OSAS and COVID-19. Herewith, presenting this clinical perspective is two-fold. First, OSAS may be a risk factor for mortality or deteriorate the clinical scenario in COVID-19. Therefore, keeping in mind the modulating effects of sleep on the

Ahmet Cemal Pazarlı

dracp60@gmail.com

1 Department of Pulmonary Diseases, Faculty of Medicine, Gaziosmanpaşa University, Tokat, Turkey

2 Department of Physical and Rehabilitation Medicine, Türkmenbaș Medical Center, Adana, Turkey

3 Department of Neurology, Konya Medicana Hospital, Konya, Turkey immune system, proper treatment of OSAS patients may be protective/beneficial in COVID-19. Second, patients who suffered from COVID-19, particularly severe cases, may be under risk for OSAS due to pulmonary fibrosis. Clinicians should be cautious against the OSAS presence during the later periods in relevant patients.

\section{Compliance with ethical standards}

Conflict of interest The authors declare that they have no conflict of interest.

\section{References}

1. Zhou F, Yu T, Du R et al (2020) Clinical course and risk factors for mortality of adult inpatients with COVID-19 in Wuhan, China: a retrospective cohort study. Lancet 395(10229):1054-1062

2. South AM, Diz D, Chappell MC (2020) COVID-19, ACE2 and the cardiovascular consequences. Am J Physiol Heart Circ Physiol 318: H1084-H1090. https://doi.org/10.1152/ajpheart.00217.2020. (inpress)

3. Barceló A, Elorza MA, Barbé F, Santos C, Mayoralas LR, Agustí AGN (2001) Angiotensin converting enzyme in patients with sleep apnoea syndrome: plasma activity and gene polymorphisms. Eur Respir J 17(4): 728-732

4. Pinto JA, Ribeiro DK, Cavallini AF, Duarte C, Freitas G (2016) Comorbidities associated with obstructive sleep apnea: a retrospective study. Int Arch Otorhinolaryngol 20(2):145-150

5. Ye Z, Zhang Y, Wang Y, Huang Z, Song B (2020) Chest CT manifestations of new coronavirus disease 2019 (COVID-19): a pictorial review. Eur Radiol. https://doi.org/10.1007/s00330-020-06801-0. (inpress)

Publisher's note Springer Nature remains neutral with regard to jurisdictional claims in published maps and institutional affiliations. 